\title{
Weisure - fenomén, životní styl, nebo zlozvyk? Martina Kočerová
}

\begin{abstract}
Abstrakt
Článek se zabývá fenoménem weisure a změnami, které tento fenomén přináší v oblasti volného času. Jde o teoretickou studii, jejímž cílem je ukázat na úlohu pedagogiky volného času v moderní západní společnosti, kde dochází k rozvolnění hranice mezi časem práce a volným časem. Článek dochází k závěru, že z pohledu pedagogiky volného času je žádoucí působit na jedince již v dětství, kdy se utváří základ osobnosti a formuje se hodnotová orientace. Volný čas nepojímá primárně jako časový prostor ale spíše jako důležitou životní polohu, která významně ovlivňuje vyváženost života každého jedince a také společnosti jako celku. Pedagogika volného času by se měla v prevenci životního stylu weisure zaměřit zejména na rozvoj volnočasových kompetencí, hodnotovou výchovu, kritické myšlení a socializaci. A naopak - výchova ve volném čase by se neměla orientovat na pouhou realizaci aktivit a činností, a to i přes jejich atraktivitu, zábavnost či smysluplnost. Pokud se totiž zamění výchovné pưsobení ve volném čase za pouhé naplnění volného času aktivitami a činnostmi, dochází k instrumentalizaci volného času a rozvoji životního stylu weisure. Namísto učení se zacházet se svobodou, zodpovědností, vytrvalostí, místo hledání smyslu se dítě učí konzumovat volnočasové aktivity, bavit se a selektivně si vybírat dle momentální nálady či módy. Volný čas jako časová kategorie z života člověka nevymizel, smazává se však podstata volného času, která je do velké míry ovlivněna instrumentalizací a pedagogizací volného času. Volný čas nabývá charakteru povinnosti, čímž je snižován potenciál, kterým volný čas disponuje. A právě tento vývoj podtrhuje význam pedagogiky volného času, která by měla své úsilí zaměřit nejen na děti a mládež, ale také na edukaci rodičů a pedagogů volného času, kteří se na instrumentalizaci a pedagogizaci volného času v mnohém podílí.
\end{abstract}

Klíčová slova: hodnotová výchova, instrumentalizace volného času, intravidual, pedagogika volného času, pedagogizace volného času, volný čas, volnočasové kompetence, weisure

\section{Úvod}

Zdá se, že ve světě poměrně hojně diskutovaný fenomén weisure zatím nevzbuzuje v českém prostředí př́liš pozornosti. Pokud je mu věnován prostor v odborném tisku, pak je to zejména v oblasti sociologie, nikoliv pedagogiky, což platí i pro většinu zahraničních pojednání. To ovšem neznamená, že by česká společnost tímto fenoménem nebyla zasažena. Obdobně jako v jiných technologicky vyspělých zemích je také v České republice běžnou součástí života užívání 
nejmodernějších technologií. I v ČR se stále častěji setkáváme s tím, že mizí jasná hranice mezi prací a volným časem, mezi privátní a veřejnou sférou, mezi ryze pracovními a volnočasovými aktivitami.

Volný čas je stále pro mnoho lidí časovým úsekem, v němž je možné nebo nutné si odpočinout po práci, at již aktivně, či pasivně. Pro jiné je to čas seberealizace a kompenzace nenaplněných potřeb, tužeb a přání v čase práce. Mnozí se ve volném čase chtějí bavit a užít si života a - možná paradoxně - zapomenout na starosti s životem spojené. Čím dál početnější skupina lidí má ale pocit, že si nemůže dovolit odložit pracovní povinnosti a mít volný čas, a tudíž je stále on-line. Rozšiřuje se také okruh lidí, zejména mladých, v jejichž životě se volnočasové aktivity stávají součástí práce. Jak lidé pojímají volný čas a co od volného času očekávají, poukazuje na jejich pojetí života jako celku.

Weisure a změny v uspořádání života moderní západní společnosti se nachází v recipročním vztahu. Zatímco život současných prarodičů byl jasně strukturován co do času, prostoru i sociálních rolí, život dnešních mladých lidí vykazuje značné změny. Hranice se smazávají, moderní technologie umožňují nejen vykonávat několik věcí najednou, ale dokonce být na několika místech současně. Možné je i být v jeden okamžik v několika různých časech, s různými lidmi, v různých kulturách. Práce a zábava se prolínají, někdy dokonce zcela splývají, a není zřejmé, co je práce a co zábava. Člověk ztrácí jasné hranice a přestává si být jist dokonce sám sebou. Disponuje sice značnou svobodou, kterou ale nedokáže uchopit, nebot mu chybí referenční rámce, tolik potřebné pro rozhodování a budování identity. Vzniká intravidual - jedinec nerozlišující hranice, zpochybněný, nejistý. ${ }^{1}$

Byt’ pro některé lidi mizí hranice mezi prací a volným časem, čímž dochází ke zpochybnění životního prostoru volného času, přesto význam pedagogiky volného času není umenšen. Právě naopak, životní styl weisure přináší pro pedagogiku volného času nové výzvy a je třeba, aby se s nimi vypořádala.

\section{Co je weisure}

V roce 2009 vyšel na webových stránkách CNN článek Welcome to the „weisure “ifestyle², pojednávající o trendu nazývaném anglicky weisure 3 . Jedná se o fenomén, který se vyznačuje rozostřením hranice mezi prací a volným časem. Nepostihuje jen americkou společnost (kde byl poprvé popsán), ale vyskytuje se kdekoliv, kde moderní technologie a virtuální realita infiltrovaly život člověka. Jde o jev, se kterým se můžeme setkat také v současné české společnosti.

Název weisure použil poprvé americký sociolog Dalton Conley, který ve své knize Elsewhere, U.S.A. ${ }^{4}$ porovnává životní styl svých prarodičů, rodičů a svých současníků. Všímá si rozdílů týkajících se zejména hranice mezi časem stráveným v práci a volným časem, která se postupně rozvolňuje. Zatímco v životě prarodičů je tato hranice zcela zřetelná, pracovní čas se výrazně lišil od času volného a pracovní činnosti od volnočasových aktivit, u současné generace mnohdy tuto

1 Srov. Dalton CONLEY, Elsewhere, U.S.A.: How We Got from the Company Man, Family Dinners, and the Affluent Society to the Home Office, BlackBerry Moms, and Economic Anxiety, New York: Pantheon Books, 2008, s. 156-171; Srov. () Dalton CONLEY, Rich man's burden, The New York Times, September 2, 2008, dostupné na: https://www.nytimes.com/2008/09/02/opinion/02conley.html; Srov. Gilles LIPOVETSKY, Les temps hypermodernes, Paris: Editions Grasset \& Fasquelle, 2004, s. 8-148; Srov. Manfred SPITZER, Cyberkrank!, München: Droemer Verlag, 2015, s. 25-46.

2 Srov. (C) Thom PATTERSON, Welcome to the „weisure“ lifestyle. CNN. May 11, 2009, dostupné na: http://edition.cnn.com/2009/ LIVING/worklife/05/11/weisure/?iref=nextin.

3 Jde o spojení dvou anglických slov - work a leisure. V českém jazyce neexistuje ke slovu weisure jazykový ekvivalent. Dictionary.university (online), heslo: weisure.

4 Srov. CONLEY, Elsewhere..., s. 31. 
jednoznačnou hranici nenalézáme (at již sledujeme časové rozlišení, nebo aktivity považované za typicky pracovní a typicky volnočasové). Zatímco prarodiče pracovali proto, aby v čase důchodu mohli odpočívat a věnovat se svým zálibám, současný člověk často pracuje a opět pracuje. Život prarodičů byl strukturovaný a bylo jasně dáno nejen kdy, ale také kde se pracuje - kdy a kde a s kým se tráví volný čas. Současný člověk nejenže se může velmi rychle přemistovat $\mathrm{z}$ místa na místo, ale díky moderním technologiím může být na několika místech současně. Smazává se tak hranice nejen prostorová a časová, ale člověk může ve stejnou chvíli pracovat i bavit se - současně být i nebýt $\mathrm{v}$ práci. $^{5}$

Také tradiční rozdělení rolí v rodině mizí. Dříve bylo jasné, kdo vaří, kdo se stará o zahradu, kdo o dům či domácnost. Dnes se členové rodiny obvykle během dne stravují každý zvlášt a mimo domov, společně strávený čas u jídla je velmi omezený. Děti vyzvedává ze školy a vozí na kroužky ten $\mathrm{z}$ rodičủ, kdo má právě méně nabitý program, a pokud je rodina spolu, velmi často jde jen o fyzickou př́tomnost, nebơ jednotliví členové rodiny jsou právě on-line někde jinde, nebo jsou vyrušováni vyřizováním telefonátů, emailů apod. Většina času je vlastně časem, který současná moderní společnost tráví prací, at už je člověk fyzicky kdekoliv. ${ }^{6}$

Změny se týkají zejména tří životních oblastí - ekonomiky, rodiny a technologií - a dávají zrod novému typu člověka nazývanému intravidual ${ }^{7}$ Ten je doslova bombardován nesčetnými stimuly v jeden jediný okamžik, jako by se pohyboval ve více světech zároveň. Samožrejmě ne všichni lidé žijí tímto životním stylem, nicméně vlivem těch, kteří tak žijí, se mění „hrací pole“ i pro ostatní, nebot modernistické rozdělení (pojednané v následující kapitole) domov - kancelář, práce - volný čas, veřejné - privátní a dokonce i já - ti druzí již neplatí. Hranice mezi prací a domovem mizí, technologie formují rodinný život, práce proniká do volného času a naopak. Činnosti a společenské prostory se stávají nejednoznačnými, přestává být jasné i to, co je vlastně práce a co zábava, nebo, co je pracovní nástroj a co hračka. Rozmlžení hranic má za následek neustálou rozkolísanost a nejistotu. ${ }^{8} \mathrm{~V}$ důsledku oslabování významu předepsaných způsobů chování (jak tomu bylo v moderní společnosti), s prohlubující se personalizací (provázející dobu postmoderní) a s důrazem na jednání, které je založené na osobní volbě a zodpovědnosti, dost možná není ani jasné, kde by se jedinec měl nacházet a co by měl dělat. ${ }^{9}$

Životním stylem weisure jsou ovlivněni zejména ti, kteří pracují mentálně a ke své práci využívají moderní technologie. Jde o skupinu lidí propojených sociálními sítěmi, které jsou nevyhraněné a mohou představovat jak zdroj zábavy, tak pracovní prostředí. Souputníci on-line světem mohou být - a často i skutečně jsou - zároveň přáteli i pracovními partnery. Jsou to ale také děti a mladí lidé, jejichž životní prostř̌edí je již neodmyslitelně spjato s moderními technologiemi, které tak formují základ pro jejich životní styl v budoucnosti. ${ }^{10}$

5 Srov. tamtéž, s. 141-155; Srov. LIPOVETSKY, Les temps..., s. 11-30.

6 Srov. CONLEY, Elsewhere..., s. 141-155; Srov. LIPOVETSKY, Les temps..., s. 11-43.

7 Jde o osobu, která nerozlišuje hranice mezi domovem a místem práce, protože její pozornost je neustále přitahována rozmanitými toky informací. Definition - Of. Community dictionary by Farlex (online), heslo: intravidual.

8 Srov. CONLEY, Elsewhere..., s. 141-155; Srov. PATTERSON, Welcome...; Srov. C Eric STODDART, „Fuelled by dreams and powered by imagination“: Considering digital technologies through the lens of a theology of play. Practical Theology 1/2015, dostupné na: https:// doi.org/10.1179/1756074815Y.0000000002, s. 19-40; Srov. Manfred SPITZER, Demencia digital, Barcelona: Ediciones B, 2013, s. 27-103; Srov. SPITZER, Cyberkrank!..., s. 25-46.

9 Srov. Gilles LIPOVETSKY, Lére du vide. Essais sur l'individualisme contemporain, Paris: Editions Gallimard, 1983 , s. 7-99.

10 Srov. CONLEY, Elsewhere..., s. 141-170; Srov. (C) Fred LEE, Living a life of weisure? WiseBread. Liing large on a small budget, May 20, 2009, dostupné na: https://www.wisebread.com/living-a-life-of-weisure; Srov. PATTERSON, Welcome...; Srov. Robert. A. STEBBINS, New Directions in the Theory and Research of Serious Leisure. New York: Mellen Press, 2001, s. 13-185; Srov. STODDART, „Fuelled...“; Srov. SPITZER, Cyberkrank!..., s. 141-155. 


\section{Weisure a moderní pojetí volného času}

Weisure-time je obousměrný koncept, kdy lidé ve svém volném čase vyřizují pracovní záležitosti a na dovolenou jezdí jen tam, kde je on-line připojení. Mohou tak být stále ve spojení a kdykoliv je třeba, mohou se do pracovních záležitostí vložit; př́ípadně tráví víkendy v práci. V posledních letech jde ale stále častěji o opačný směr prolínání práce a volného času - zábava, čas trávený na sociálních sítích, chatování s přáteli jsou realizovány během práce. Jde ale skutečně o nový jev, nebo o návrat $\mathrm{k}$ obdobnému pojetí života, jaké bylo před vymezením životní kategorie volného času, jak ji známe v moderní společnosti?

$\mathrm{S}$ konceptem volného času (v pojetí scholé) je možné se setkat již v antice, ${ }^{11} \mathrm{kde}$ volný čas poskytoval př́ležitost pro osobní přemýšlení, promýšlení života, objevování vlastní spirituality a byl protikladem fyzické práce. Byl nejen časem, ale také stavem považovaným za vytoužené bytí a za cestu k pokroku prostř̌ednictvím intelektuální, kontemplativní a estetické činnosti, byl součástí životního stylu a hledáním kvality života. Nicméně byl výsadou především svobodných pánů, demokratizace volného času je až moderním fenoménem. ${ }^{12}$

$\mathrm{Na}$ volný čas jakožto obdobu scholé nahlíží i někteří moderní autoři. Jedním z nich je Pieper ${ }^{13}$, který představuje volný čas jako vnitřní stav duše charakteristický ne-aktivitou, která je protikladem ideálu přecenění práce (ve smyslu antického $\sigma \chi 0 \lambda \eta ́$ ). Jde o postoj slavení, v němž nejen že není námaha, ale jde př́mo o její protiklad provázený klidem a vyčleněním se ze sociální funkce. Vlastním smyslem volného času je zůstat člověkem, což znamená porozumět si a realizovat se jako bytost, která je zaměřena na celek skutečnosti.

Za předchůdce volného času lze považovat festivaly a svátky, které bývaly časem úniku z rutiny, stresu a jednotvárnosti každodenního života. Ale nejen to, společně prožitý čas, kdy si lidé připomínali důležité události $\mathrm{z}$ historie svého kmene nebo národa, upevňoval pospolitost, kmenovou či národní identitu a vědomí toho, že člověk někam patř́í, není sám, ale má historii a má také budoucnost. Zároveň šlo také o události, které rozměřovaly čas, nebot přicházely v pravidelných intervalech v průběhu roku či života, a dávaly tak možnost zastavit se, rekapitulovat, rozjímat, plánovat a připravit se na to, co přijde po nich. Člověk tak mohl shodit tíhu minulosti a upř́t svůj zrak $\mathrm{k}$ věcem budoucím $\mathrm{v}$ perspektivě svého života jako celku. ${ }^{14}$

Podle Maslowa ${ }^{15}$ jsou nejvyššími potřebami člověka potřeba někam patřit, uznání, úcta a seberealizace. Na rozdíl od tohoto pojetí existují i taková, jež za nejvyšší potřebu považují hledání toho, co má pro člověka povahu nejhlubší i nejvyšší hodnoty, povahu posledního smyslu, jak je možné zahlédnout např́iklad u Frankla ${ }^{16}$. Jde o nalezení toho, co člověka přesahuje, a to lze jedině tehdy, pokud v životě člověka bude čas či postoj kontemplace a slavení. S Franklovým názorem vstupuje do polemiky Lipovetsky ${ }^{17}$, který tvrdí, že proces personalizace, který provází postmoderní dobu a proměnu časovosti, systematicky odstranil vše transcendentní a člověku zůstává jen čistě aktuální a zcela subjektivní. Postmoderní člověk žije tedy život, který je zcela bez cíle a beze smyslu a ve kterém je vydán napospas závratnému sebeokouzlení.

11 Srov. ARISTOTELES, Etika Níkomachova, Praha: Rezek, 2013.

12 Srov. Christopher R. EDGINTON - Rodney B. DIESER - Donald G. DEGRAAF, Leisure and Life Satisfaction. Foundational Perspectives, Boston: McGraw Hill, 2006, s. 29-41; Srov. Karl MARX, Das Kapital. Kritik der politischen Ökonomie, Berlin: Dietz Verlag, 1959; Srov. Jürgen HABERMAS, The structural transformation of the public sphere, Cambridge/Massachusetts: Tha MIT Press, 1991, s. 141-180. (O)

Srov. Michal KAPLÁNEK (Ed.), Volný čas a jeho význam ve výchově, Praha: Portál, 2017, s. 6-30.

Srov. () Abraham H. MASLOW, A theory of human motivation, Psychological Reviw 4/1943, dostupné na: http://dx.doi.org/10.1037/ h0054346, s. 370-396.

16 Srov. Zuzana SVOBODOVÁ, Nelhostejnost: Črty k (ne)náboženské výchově, Praha: Malvern, 2004, s. 15-28.

17 Srov. LIPOVETSKY, L’ére du vide..., s. 7-99. 
Ve stř̌edověku bylo volno spojováno s tržní nečinností obchodníků, zároveň svou odezvu nacházela i aristotelská tradice, a to $\mathrm{v}$ důrazu na kontemplativní život (vita contemplativa), který měl být vyvážením života praktického (vita activa). Teprve humanismus přinesl spojení volného času $s$ atributem osobní svobody, kterou ještě více zdůraznilo osvícenství. Podle Nahrstedta ${ }^{18}$ mělo právě osvícenství, které akcentovalo ideál svobody, rozhodující vliv na moderní pojetí volného času. Ve svých úvahách přitom navazoval na osvícenecké autory. ${ }^{19}$

Až v období industrializace se ale formuje volný čas v moderním pojetí, kdy je jasně daná pracovní doba a člověk po odchodu $\mathrm{z}$ práce tráví čas $\mathrm{v}$ privátní zóně, která je vyplněna volnočasovými aktivitami, časem s rodinou a přáteli. Za faktory, které vedly $\mathrm{k}$ modernímu rozdělení života na sféru veřejnou a privátní, lze považovat následující tři: místo zaměstnání je odlišné od bydliště; je jasně dána pracovní náplň; za čas strávený na pracovišti či za splněný pracovní úkol náleží mzda. ${ }^{20}$ Zatímco první dva faktory se uplatňovaly ve školství ještě před industrializací, ${ }^{21}$ třetí je spojen právě s obdobím průmyslové revoluce. Došlo tak $\mathrm{k}$ rozdělení života na sféru veřejnou a privátní, na čas povinnosti a čas volna. Období industrializace je spojené s dalším faktorem, který významně zasáhl do zmíněného rozdělení času. Byla jím délka pracovní doby a právo na dovolenou. Vize o snížení pracovní doby a rozšíření práva na volný čas pro všechny vyslovili již utopističtí socialisté, ${ }^{22}$ nicméně až Marxův ${ }^{23}$ požadavek demokratizace volného času se stal jedním z cílů sociálního hnutí za sociální spravedlnost, které vyústilo v postupné snižování pracovní doby a ustanovení práva na dovolenou pro všechny. ${ }^{24}$

\subsection{Volnýčas - zbytkový čas}

Moderní doba akcentovala disciplínu vedoucí k normalizovanému a standardizovanému chování a $\mathrm{k}$ formování co nejlepších výrobních schopností. ${ }^{25}$ Logickým vyústěním těchto důrazů bylo formování volného času v závislosti na vzniku a rozvoji zaměstnaneckých vztahů a vymezování vzhledem k povinnostem, zejména pak k práci. ${ }^{26} \mathrm{~S}$ tím souviselo také chápání volného času, který byl spojován především $s$ odpočinkem po práci a na další práci ${ }^{27}$ a s kompenzací toho, čeho se v čase povinností nedostává. ${ }^{28} \mathrm{~V}$ návaznosti na popsaný vývoj došlo $\mathrm{k}$ restrukturalizaci života lidí

18 Srov. Wolfgang NAHRSTEDT, Freizeitpädagogik in der nachindustriellen Gesellschaft, Neuwied/Darmstadt, 1974, s. 18-64; Srov. Wolfgang NAHRSTEDT, Freizeitpädagogik, In: Helmwart HIERDIES ed., Taschenbuch der Pädagogik, Bd. 1., Baltmansweiler: Pädagogischer Verlag, 1986, s. 222-235.

19 Srov. NAHRSTEDT, Freizeitpädagogik in der nachindustriellen...; Srov. NAHRSTEDT, Freizeitpädagogik..., s. 18-64; Srov. KAPLÁNEK, Volný čas..., s. 6-30.

20 Srov. HABERMAS, The structural..., s. 141-180; Srov. KAPLÁNEK, Volný čas..., s. 6-30; Srov. Horst OPASCHOWSKI, Pädagogik der freien Lebenszeit, 3. Aufl., Opladen: Leske+Budrich, 1996, s. 28-56.

21 Srov. Jan A. KOMENSKÝ, Didactica magna, Brno: Komenium, učitelské nakladatelství, s.r.o., 1948, s. 91-162.

22 Srov. Thomas MORE, Utopia, Indianapolis: Hackett, 1999; Srov. Tommaso CAMPANELLA, La città del Sole, Milan: Feltrinelli, 2004; Srov. Francis BACON, New Atlantis, Manchester: Manchester University Press, 2002.

23 Srov. MARX, Das Kapital...

24 Na základě čl. 424 Versailleské smlouvy se konala ve Washingtonu od 28. 10. do 30.11. 1919 mezinárodní konference pracujících, která schválila návrh osmihodinového pracovního dne a čtyřicetihodinového pracovního týdne. Tento požadavek (zejména osmihodinové pracovní doby) se důrazně zopakoval na mimořádném Sjezdu odborů Mezinárodního odborového svazu v r. 1920 v Londýně. (Údaje dle: Franz OSTERROTH - Dieter SCHUSTER, Chronik der deutschen Sozialdemokratie, Hannover: Dietz Verlag, 1963, s. 234 a 256, cit. dle Nahrstedta); Srov. OPASCHOWSKI, Pädagogik der freien Lebenszeit..., s. 28-56; Srov. Michal KAPLÁNEK, Pedagogika volného času - projekt budoucnosti, nebo slepá ulička?, Pedagogika 1/2010, s. 12-20; Srov. KAPLÁNEK, Volný čas..., s. 6-30; Srov. Hermann GIESECKE, Zur Geschichte der Freizeit und ihrer Erforschung. In: Hermann GIESECKE (Ed.), Freizeit und Konsumerziehung, Göttingen: Vendenhoek u. Ruprecht, 1968, s. 9-18.

25 Srov. Gilles LIPOVETSKY, L’empire de l’ephémère. La mode et son destin dans les sociétés modernes, Paris: Editions Gallimard, 1991.

26 Srov. KAPLÁNEK, Volný čas..., s. 3-12.

27 Srov. GIESECKE, Zur Geschichte..., s. 9-18.

28 Srov. HABERMAS, The structural..., s. 141-180; Srov. Horst OPASCHOWSKI, Pädagogik der Freizeit. Grundlegung für Wissenschaft und Praxis, Bad Heilbrunn: Klinkhardt, 1976, s. 23-56. 
v moderní společnosti, jak je popisována v kapitole 1, a k vymezení volného času jakožto reziduální kategorie, jejíž hodnota se odvíjí především od práce. ${ }^{29}$

O takto nahlíženém volném čase pojednává Filipcová30 ${ }^{30}$ která jej spojuje s možností zvolit si činnosti, jimiž jedinec tento čas naplní. Zároveň připouští možnost upřednostnění nečinnosti, když poukazuje na to, že ve volném čase člověk „může“, ale „nemusi“, a tento pocit už sám o sobě považuje za bohatství. Polemizuje tak do jisté míry například $s$ Petrosjanem ${ }^{31}$, jenž volný čas chápe zejména jako sféru „prosté reprodukce pracovní síly““32 Filipcová není první, kdo vyslovil nesouhlas s pojetím volného času jen jako „prodloužené ruky práce“. Již v roce 1880 publikoval Paul Lafargue spisek v českém překladu nazvaný Právo na lenost ${ }^{33}$, v němž deklaruje právo člověka volně nakládat se svým časem - tedy i s volným časem.

Filipcová poukazuje na to, že:

„způsob, jak se pracovní síla reprodukuje v mimopracovní době obecně a ve volném čase zejména, se pochopitelně zpětně odráží ve výrobním procesu samém. Jenomže člověk přece není pouhá pracovní síla - být pracovní silou, to není jeho jediná společenská a lidská role. Redukovat lidskou osobnost na pracovní sílu znamená učinit z výroby konečný smysl a cíl lidských dějin. Znamená to, že člověk existuje a žije, protože vyrábí, že tedy existuje a žije proto, aby vyráběl? Zúžení pohledů na volný čas do této jediné roviny vede i k určitým zjednodušujícím schématům v názorech na pozitivní či - jak se často říká - racionální nebo efektivní využívání volného času. “ ${ }^{34}$

Ve svém pojetí volného času nezapomíná ani na sféru rekreace. ${ }^{35}$ Připomíná, že činnosti volného času nemusí vždy být v prvé řadě spojeny s výsledkem v podobě konkrétního výtvoru, ale také s prožitkem, požitkem nebo poznatkem. Volný čas se taktéž podílí na utváření životního způsobu a umožňuje rozvíjení participace $v$ dané kultuře. ${ }^{36}$

S odlišným atributem spadajícím do volného času přichází Červinka ${ }^{37}$, který vidí volný čas ve spojení s výchovou dětí a upozorňuje, že sem nelze zařazovat činnosti spojené s př́pravou jídla, úklidem domácnosti, nákupem a pasivním odpočinkem.

Vážanský38 ${ }^{38}$ řipomíná, že člověk často transferuje v práci osvojené vzorce chování do úseku volného času a opačně (tzv. kongruenční teorie volného času). Taktéž se zamýšlí nad tím, že volný čas je sice sférou svobody a svobodné volby, avšak je zde jisté ohraničení možností využívání kapacity volného času pracovními limity, nejrůznějšími bariérami a předsudky, nebot’ dochází k aplikování repertoáru pracovních modelů jednání i v této oblasti relativní svobody.

Hovoří o tzv. hypotéze shody s teoriemi redukce, generalizace a identity. Kromě této hypotézy existuje ještě hypotéza kontrastu s teoriemi kompenzace, ventilu a zotavení. Obě tyto hypotézy patři k tzv. negativnímu vymezení volného času, jenž chápe volný čas jako prací podmíněný prostor jednání. Tento přístup k volnému času předpokládá, že v práci člověk potlačuje své emoce,

29 Srov. KAPLÁNEK, Volný čas..., s. 6-30.

30 Srov. Blanka FILIPCOVÁ, Člověk, práce, volný čas, Praha: Svoboda, 1966.

31 Srov. S. G. PETROSJAN, Vněrabočeje vremja trudjaščichsja v SSSR, Moskva, 1965, s. 12.

32 Srov. FILIPCOVÁ, Člověk..., s. 50.

33 Srov. Paul LAFARGUE, Le Droit à la Paresse. Éditions de la République des Lettres. Publication numérique (format ePub), 2012.

34 FILIPCOVÁ, Člověk..., s. 50.

35 Srov. tamtéž, s. 24-25.

36 Srov. Blanka FILIPCOVÁ, Volný čas a kultura v průmyslovém městě, Praha: Ústav pro kulturně výchovnou činnost, 1974, s. 24-25.

37 Srov. Antonín ČERVINKA, Volný čas a pracovní den, Nová mysl 11/1962, s. 1292.

38 Srov. Mojmír VÁŽANSKÝ, Základy pedagogiky volného času. 2. doplněné vydání, Brno: Print-Typia, 2011, s. 30-32. 
prožívá celou řadu latentních strachů, nepokojů, nejistot a stresu vedoucích k psychickému napětí a vnitřnímu neklidu a vše toto následně kompenzuje ve svém volném čase, což je předpokladem a zárukou zdraví a dobré pohody. ${ }^{39}$

Jiným pojetím je tzv. pozitivní, které nahlíží na volný čas jako na samostatnou oblast života, která má hodnotu sama o sobě a poskytuje místo k růstu, ke hledání smyslu života a identifikaci, je prostorem pro objevování pravých kvalit života s možností seberealizace a uspokojování potřeb. ${ }^{40}$ Do jaké míry se tzv. negativní a pozitivní pojetí volného času liší, je otázkou. Každé z nich nahlíží na volný čas z jiné strany, nicméně u obou je zdůrazněn protiklad práce a volného času, dvou oblastí života téhož jedince, jež jsou vůči sobě ve vztahu poměrně nepřátelském a tudíž neslučitelném. Avšak pozitivní chápání volného času se přece může stát východiskem pro celistvější př́stup podporující myšlenku lidské jednoty, jak tomu je u přístupu, který chápe člověka jako nedělitelnou bytost a ne jako jedince složeného z pracujícího tvora na jedné straně a volnočasové osoby na straně druhé. Práce a volný čas se v takovém př́padě nemohou posuzovat jako navzájem oddělená autonomní pole, v obou musí být uspokojena základní potřeba seberealizace, relativní nezávislosti a smyslu života, což přispívá jak k mnohostrannému vývoji osobnosti, tak podněcuje okolní prostředí.

\subsection{Volný čas - leisure}

Tak, jak se v historii vyvíjela společnost, procházely vývojem i všechny oblasti lidského života včetně volného času. Pojetí volného času jakožto zbytkové kategorie vzhledem k práci (které bylo popsáno v kapitole 2.1) tak není jediným, se kterým se můžeme setkat.

$\mathrm{V}$ anglicky mluvících jazykových oblastech, kde je rozvíjen anglosaský badatelský proud tzv. leisure studies (někde také leisure sciences), ${ }^{41}$ se setkáváme se dvěma pojmy, které v češtině odpovídají volnému času. Jsou jimi free time a leisure, přičemž free time označuje spíše časový úsek, zatímco leisure je vícerozměrným konceptem. Někdy je leisure popisován jako důležitá společenská, kulturní a ekonomická síla, která má významný vliv na pocit štěstí, spokojenosti, zdraví a duševní pohody v životě každého jedince. Leisure je spojen s relativní svobodou od nátlaku či omezení, je spojen s pocitem pozitivního dopadu, je motivován vnitřní touhou a dovoluje objevovat a uplatňovat schopnosti daného jedince. $\mathrm{V}$ americké společnosti se pojem leisure začal používat ve 40. letech minulého století a postupem času se jeho význam ustálil ve smyslu leisure jako cesty, jak přinášet rovnováhu do života jedince. Jde nejen o hledání možností relaxace, seberozvoje, kulturní a rodinné stability a interakce, ale taktéž o možnost úniku, originality, komplexnosti, dobrodružství, vzrušení a fantazie. ${ }^{42}$

Stebbins, jeden $\mathrm{z}$ autorů zabývajících se problematikou leisure a free time, ${ }^{43}$ popisuje zmíněné dva koncepty následovně. Leisure označuje dobrovolně zvolené aktivity, kterým se člověk chce věnovat a které samy o sobě nebo cesta $\mathrm{k}$ jejich realizaci přináší uspokojení; ve kterých může uplatnit své schopnosti, nápady a být úspěšný a jimž se věnuje v době označované za free time. Free time je časem mimo nepřijemné povinnosti, s př́ijemným závazkem býti potěšen (či pohoštěn, léčen), jako podstata leisure již od homo otiosus - leisure man. ${ }^{44}$

39 Srov. tamtéž.

40 Srov. tamtéž

41 Srov. Tony BLACKSHAW, Leisure, London: Routledge, 2010.

42 Srov. EDGINTON - DIESER - DEGRAAF, Leisure..., s. 31-38.

43 Srov. STEBBINS, New Directions...; Srov. Robert. A. STEBBINS, Serious Leisure. A Perspective for Our Time, New Brunswick: Transaction Publishers, 2007, s. 1-5.

44 Leisure man je člověk, jemuž bohatství a/nebo sociální pozice dovoluje zabývat se příjemnými společenskými, kulturními a sportovními 
Na základě této definice pojmu free time by se mohlo zdát, že se alespoň co do času a prostoru jedná o širší pojem, než je leisure, nebot free time je zde pojímán jako čas svobodný od povinností, a je tedy volný k tomu, aby s ním jedinec naložil dle svého uvážení. Využije-li jej k leisure či jakkoli jinak, je na jeho svobodné volbě, a tedy můžeme říci, že leisure se může stát náplní free time. Avšak vyvstává otázka, zda lze free time naplnit také něčím jiným, než je leisure? Nebo snad platí, že každá náplň free time je leisure? A platí snad, že každý leisure je také free time? Nebo můžeme říci, že leisure má své vymezení na základě kvality činností a lze ho mít kdekoli a kdykoli - včetně free time, kdežto free time má jasně vymezené hranice právě tím, že se odehrává výhradně mimo práci a povinnosti a je prostorem určeným k smysluplnému využití? Pokud by platilo posledně zmíněné, pak by nebylo možné s takovou jistotou tvrdit, že free time je širším pojmem než leisure, a dále by bylo znesnadněno porovnání jejich šíře jako takové, nebot’ jsou založeny na odlišných paradigmatech. Leisure je vymezen na základě kvality činnosti, kdežto free time je odvozen od kvality času.

Stebbin $\mathrm{s}^{45} \mathrm{k}$ tomu podotýká, že někdy bývá výraz free time používán záměnně k leisure. Ve svém free time je možné se nudit následkem nicnedělání nebo aktivity, která je nezajímavá, nepodnětná. Stejná situace však může nastat v práci nebo taktéž při plnění jiných než pracovních povinností. Pokud je nuda považována za negativní stav mysli, pak lze namítat, že nejde o leisure, nebot’ pro leisure je typický pozitivní přístup, mimo jiné také tvořený názory, radostným očekáváním a vzpomínkami na prožité činnosti a situace. Samozřejmě se ale může stát, že očekávání jedince bude nerealistické, čímž se začne nudit a přetvářet je v něco zcela odlišného od leisure. A to vše se může odehrávat $\mathrm{v}$ rámci free time, což dobře ilustruje, jak může tento čas obsáhnout širší oblast života než leisure, jenž se nachází uvnitř tohoto času.

Stebbins ${ }^{46}$ rozlišuje mezi serious leisure a casual leisure, avšak pokud bychom tato dvě pojetí spojili, pak je leisure zdrojem neformálního experimentování, náhodného objevování a spontánního vynalézání, a tedy hlavním zdrojem pocitu štěstí. Leisure je dále spojován s trvalým užitkem, jako je seberealizace, sebeobohacení, posílení sebehodnocení - tudíž identity, ${ }^{47}$ a upevnění a rozvinutí schopností a strategií k osobnímu a sociálnímu začlenění. Taktéž je spojen s produkcí sociálního kapitálu, se zvýšením smyslu sounáležitosti mezi individuálním sebepotvrzením nezávislosti a mezi jednotlivcem a skupinou, což je umožněno díky síti vztahů, jež je základem pro vzájemnost a oboustrannou pomoc $\mathrm{v}$ př́ípadě potřeby. ${ }^{48}$

Havighurst ${ }^{49}$ a Kaplan ${ }^{50}$ spojují leisure především s participací na životě společnosti at již v širším, či užším měřítku, tedy s místní komunitou, dále pak se vzděláváním, seberozvojem a trvalým užitkem. Havighurst ${ }^{51}$ dále leisure spojuje s dostatkem možností k zajímavému prožívání, tvůrčímu vyjádření osobnosti s tím, že akcentuje pravidelné a rutinní utváření životních činností. Leisure má být zdrojem úcty k sobě a respektování ostatních. Kaplan ${ }^{52}$ požadavek vztahu ke společnosti vyjadřuje budováním vědomí „nějak k něčemu patřit“ a domnívá se, že leisure by měl být prospěšný jak jedinci, tak společnosti (leisure lifestyle). Leisure dále spojuje s rozvojem vlastní

zájmy či zábavou spíše než zaměstnáním. Původně označení pro muže, jenž je nezávislý na majetku a který se může věnovat jakémukoli zájmu, a to během času, kdy běžný muž musí pracovat. Urban dictionary (online), heslo: man of leisure.

Srov. STEBBINS, New Directions..., s. 177-179.

Srov. tamtéž.

Srov. Shaun BEST, Leisure Studies: Themes \& Perspectives, London: SAGE Publications, 2010, s. 177-258.

Srov. STEBBINS, New Directions..., s. 177-179.

Srov. Robert J. HAVIGHURST, Employment, retirement and education in the mature years, in: Guglielmo WEBER, Aging and retirement, Gaingswill, 1955.

Srov. Max KAPLAN, Leisure in America, New York: Willey, 1960, s. 76.

Srov. HAVIGHURST, Employment. .

Srov. KAPLAN, Leisure..., s. 76. 
individuality a uváděním v soulad různých individuálních funkcí, kromě jiného tím, že přináší do života jedince pozitivní zážitky a podněcuje tvưrčí síly. Nezapomíná ani na možnost vyrovnávání tlaků, které plynou z pracovního procesu a všedního dne, a kromě vzdělávání a získávání informací vidí leisure jako významný prvek při formování životní orientace jedince.

Leisure je spojován s tvưrčím a aktivním prožíváním volného času, přičemž podle některých autorů (např. Rojka) dokonce pasivní či konzumní využívání volného času za leisure vůbec považovat nelze..$^{53}$

Vidíme, že leisure má pro rozličné lidi různé významy, jež daly vzniknout několika konceptům: leisure jako čas; jako činnost; jako stav mysli; jako kvalita aktivit; jako společenský konstrukt; jako společenský nástroj; jako protiutilitární koncept a jako součást holistického procesu. ${ }^{54}$

Pokud tedy uvažujeme o volném čase jako o kategorii reziduální (jak byl volný čas pojednán v kapitole 2.1, kdy toto pojetí navazuje zejména na sociologii rozpracovanou Weberem, Parsonsem nebo v současnosti např. Robertsem ${ }^{55}$ ), pak jde spíše o volný čas ve smyslu free time. Oproti tomu existuje tzv. pozitivní vymezení volného času (zmíněné v kapitole 2.1), které mluví předně o vytvoření prostoru - free time. Avšak zde se již předpokládá, že free time bude využit k leisure, tedy $\mathrm{k}$ aktivitám přinášejícím pozitivní rozvoj osobnosti jedince, což se promítne do jeho celkového života a životního stylu. Jak podotýká Kaplánek ${ }^{56}$, nudit se ve free time je docela dobře možné, ovšem prožívat leisure jako nudu nelze.

Jak tedy v kontextu této kapitoly uvažovat o weisure? Na rozdíl od free time, který má jasně vymezené hranice, weisure hranice rozvolňuje a tím koncept volného času narušuje, až boří (kapitola 1). Ale jak je tomu ve vztahu $\mathrm{k}$ leisure, který se nutně nemusí odehrávat v prostoru free time, a je vymezen na základě kvality činností? Díváme-li se na weisure z pohledu pozitivního rozvoje jedince $\mathrm{v}$ kontextu jak osobního života, tak společnosti (jak byl leisure pojednán $\mathrm{v}$ této kapitole), pak weisure kvalitu činností spojenou s leisure nevykazuje. Jde spíše o zlozvyk, který následně vede $\mathrm{k}$ rozvoji nezdravého životního stylu (kapitola 3 a 4). Ač se tedy fenomén weisure rodí z leisure a work (jak bylo pojednáno v kapitole 1 ), současně podstatu obou těchto základů destruuje. ${ }^{57}$

\section{Weisure jako naplnění ideálu volnočasového životního stylu?}

Zatímco dříve člověk pracoval a stoupal po pomyslném kariérním žebříčku ${ }^{58}$, aby získal více času, který bude moci trávit doma, $s$ rodinou a přáteli, dnes čím je člověk kariérně výše, tím více času tráví v práci. ${ }^{59}$ Zatímco Dumazedier ${ }^{60}$ mluvil o společnosti volného času jako o vizi budoucnosti, kdy moderní technologie umožní zkrácení pracovní doby a tím se prodlouží čas, který člověk může věnovat sám sobě, rodině, zájmům, dnes to vypadá spíše naopak. Moderní technologie jsou právě tím, co člověku umožňuje pracovat i mimo kancelář, dokonce v době volna, a pracovat tak více. Samozřejmě se změnil charakter práce, kdy alespoň část populace jejich práce baví, užívají si ji nebo alespoň některé její aspekty, nebo dokonce je jejich koníčkem. ${ }^{61}$ Ale také se změnila společnost,

\footnotetext{
53 Srov. Chris ROJEK, Leisure and Culture, New York: Palgrave Macmillan, 2000; Srov. Chris ROJEK, Leisure Theory: Principles and Practice, New York: Palgrave, 2005.

54 Srov. EDGINTON - DIESER - DEGRAAF, Leisure..., s. 38-44.

55 Srov. Ken ROBERTS, Leisure Industries, New York: Palgrave Macmillan, 2004.

56 Srov. KAPLÁNEK, Volný čas..., s. 29.

57 Srov. Ulrich BECK, Risikogesellschaft (Auf dem Weg in eine andere Moderne), Frankfurt am Main: Suhrkamp Verlag, 1986, s. 113-250.

58 Srov. Steven J. OVERMAN, The protestant ethic and the spirit of sport. How Calvinism and capitalism shaped America's games, Macon, GA: Mercer University Press, 2011, s. 17-41.

59 Srov. CONLEY, Elsewhere..., s. 141-155.

60 Srov. Joffre DUMAZEDIER, La révolution culturelle du temps libre (1968-1988), Paris: Méridiens Klincksieck, 1988 , s. 58-175.

61 Srov. EDGINTON - DIESER - DEGRAAF, Leisure..., s. 29-41; Srov. LEE, Living...
} 
která je v důsledku procesu personalizace méně uspořádána na základě vnější determinace. Mnohem více je jednání jednotlivců výsledkem podvědomého hledání sama sebe, vlastního Já. ${ }^{62}$

Marxova teorie odcizené práce ${ }^{63}$ či Habermasova kompenzační teorie ${ }^{64}$ jako by ztrácely na aktuálnosti. Volný čas je více vnímán tak, jak jej popisuje Dumazedier ${ }^{65}$, který říká, že k volnému času neoddělitelně patři nevykonávání činností pod tlakem závazků vyplývajících ze sociálních rolí, dělby práce a potřeby zachovat a rozvíjet vlastní život. Oproti tzv. zbytkové (reziduální) teorii volného času (zmíněné v kapitole 2.1) pojímá tento čas jako souhrn činností, do nichž člověk vstupuje s očekáváními a jež mu přináší př́ijemné zážitky a uspokojení. Za základní atribut volného času považuje možnost svobodného rozhodnutí.

Sue ${ }^{66}$, francouzský sociolog volného času, výše zmíněný pohled obohacuje o funkci sociální, do níž zařazuje proces socializace $\mathrm{v}$ různých sociálních prostředích, jenž vede k sebepotvrzení a k dosažení sociálního uznání. Ovšem jestli má volný čas tuto funkci i v době postmoderní (nebo hypermoderní) a do jaké míry nebo v jaké podobě může být socializační funkce volného času naplňována, je jistě námětem k diskuzi, uvědomíme-li si, že podle Lipovetského:

„vede proces personalizace k zániku socializace založené na disciplíně. Po autoritativní a mechanické drezuře přichází homeopatický a kybernetický způsob socializace; po rozkazujícím řízení přichází volitelné programování na objednávku. Proces personalizace postavil do popředí osobní realizaci a respektování subjektivní zvláštnosti a jedinečné osobitosti jakožto základní hodnotu. Právo být naprosto sám sebou a co nejvíce si užívat je totiž neoddělitelné od společnosti, která svobodu člověka povýšila na základní hodnotu, a je pouze nejzazším projevem individualistické ideologie. Společenské a individuální jednání už není motivováno snahou po univerzálnosti, nýbrž hledáním vlastní identity. “ ${ }^{67}$

U citovaných autorů (Dumazedier a Sue) si můžeme všimnout, že byṫ volnému času připisují vlastní hodnotu, která se neodvíjí od vztahu k práci, ale spíše od významu, který volný čas a volnočasové aktivity mají v kontextu života jako celku (lze porovnat s kapitolou 2.1), přesto stále uvažují o volném čase jako o časovém úseku, který je od práce oddělen jasnou hranicí. Jak bylo ale uvedeno $\mathrm{v}$ kapitole 1, tato hranice se v současné postmoderní společnosti rozvolňuje, ba dokonce $\mathrm{v}$ subjektivním vnímání některých jedinců neexistuje. Zatímco dříve lidé pracovali tvrdě, aby oni sami nebo jejich děti nemuseli pracovat, dnes čím více člověk vydělá, tím více pracuje. Zatímco dříve, když člověk vydělal peníze, prožíval svobodu ${ }^{68}$ nyní, čím více vydělá, tím větší tlak pocituje ${ }^{69}$ Být „on“ dvacet čtyři hodin sedm dnů v týdnu se stává „novou normalitou“. Jestliže se mění vzájemné postavení mezi prací a privátním životem, mění se vztah práce a volného času, práce a života - hranice se stírají. Ale jak je pak možné najít životní rovnováhu, o které se zmiňuje Pieper ${ }^{70}$ (kapitola 2)? Hannah Inam ${ }^{71}$ nabízí řešení: přestat hledat rovnováhu a začít přemýšlet, jak být plný

62 Srov. LIPOVETSKY, Lére du vide..., s. 76; Srov. LIPOVETSKY, Lempire..., s. 54.

63 Srov. MARX, Das Kapital..., s. 873-874.

64 Srov. HABERMAS, The structural...

65 Srov. Joffre DUMAZEDIER, Vers une civilisation du loisir?, Paris: Editions du Seuil, 1962, s. 46-168.

66 Srov. Roger SUE, Le loisir, Paris: Presses universitaires, 1993, s. 31-52.

67 LIPOVETSKY, Lére du vide..., s. 10.

68 Srov. HABERMAS, The structural..., s. 141-180.

69 Srov. CONLEY, Elsewhere..., s. 154-168.

70 Srov. PIEPER, Muße und Kult..., s. 43-50.

71 Srov. () Henna INAM, Forget work life balance: seven paradigm shifts for the new 24/7 normal. Forbes.com. October 7, 2013. Retrieved 
energie a kreativní v celém životě - žít život s vášní (passion) a účastenstvím (contribution). Tato výzva připomíná myšlenky Horsta Opaschowského ${ }^{72}$, který stál v 70. letech 20. století u zrodu koncepce pedagogiky volného času (Freizeitpädagogik), jejímž cílem bylo integrovat oblasti práce a volného času v jeden celek lidského života, a překlenout tak Habermasem ${ }^{73}$ popisovanou propast mezi prací a volným časem (sférou veřejnou a soukromou, jak bylo zmíněno v kapitole 1). Člověk by se měl rozvíjet v umění promýšlet a uspořádat veškerý čas svého života svobodně a současně zodpovědně, aby časové úseky, s nimiž může volně disponovat, také skutečně užíval podle svého svobodného rozhodnutí, a to k prospěchu svému i ostatních. ${ }^{74}$

Podle Inam ${ }^{75}$ by měl člověk zacílit do svého nitra ve smyslu hledání vnitřní rovnováhy místo očekávání na zásah zvenčí - na vnitřní svobodu místo očekávání na svobodné vnější okolnosti. Životní rovnováha nemůže být cílem života člověka, tedy příčinou, pro kterou člověk žije, ale má být prŕtomna v životě jakožto jeho předpoklad. ${ }^{76}$ Jako bychom se opět vraceli ke konceptu kontemplativního života (kapitola 2), se kterým se setkáváme již v době řecké filosofie akcentující životní vyváženost. Ta se zakládala na dvou sférách - aktivním životě, který zahrnoval záležitosti tohoto světa; a rozjímavém životě, jenž není obtížen tlaky života, a může se tak oddávat hledání pravdy. ${ }^{77}$ Nicméně podle Inam $^{78}$ má rovnováhu do života člověka přinést nikoliv kontemplace, ale relaxace a zábava jakožto součást pracovního procesu. Na rozdíl od času kontemplace, kdy se člověk odděloval od obstarávek běžného života, aby se mohl plně a nerušeně soustředit na nazírání za smysly vnímatelného, má se současný člověk ponořit do činnosti a být pohlcen a unášen (flow) tvưrčím procesem. Kontemplace byla předpokladem života budoucího, flow je zpřítomněním budoucnosti. ${ }^{79}$ Zábava má být cestou k odstranění toho, co by rušilo či dokonce bránilo tomuto stavu pohlcení. Zatímco kontemplace měla poskytnout prostor k reflexi a uspořádání si hodnot vedoucím k porozumění sobě samému a objevení vlastní hodnoty, flow je předpokladem života, který se vyznačuje kompletní absorpcí v tom, co člověk dělá. ${ }^{80}$ Zatímco kontemplace je cestou k vyvázání se z produkce či konzumu jakožto jediné náplni a smyslu života ${ }^{81}$ a k nalezení svobody a životní rovnováhy, flow je cestou, jak splynout s prací - už nebýt ani výrobní silou, ${ }^{82}$ ale prací samou.

Jestliže byl život moderního člověka roztříštěn do dvou sfér - práce a volného času (kapitola 2.1), které by měly být dle Opaschowského ${ }^{83}$ integrovány v jeden celek, život současného člověka, tedy životní styl weisure, sice určitou integraci vykazuje, leč jejím výsledkem není prožívání života jako celku, ale redukce života na práci, často pak práci domnělou. ${ }^{84}$ Nebot', jak upozorňuje Conley ${ }^{85}$, lidé velmi často tráví prací mnoho hodin, tudíž jim na aktivity, které by jinak dělali ve volném čase, čas nezbývá. Jenže mnoho hodin tráví prací také proto, že se na ni nesoustředí

from https://www.forbes.com/sites/hennainam/2013/10/07/forget-work-life-balance-seven-paradigm-shifts-for-the-new-247-normal/. Srov. OPASCHOWSKI, Pädagogik der Freizeit..., s. 28-56; Srov. Horst OPASCHOWSKI, Paedagogik und Didaktik der Freizeit, Opladen: Leske und Budrich, 1987, s. 32-64; Srov. OPASCHOWSKI, Pädagogik der freien Lebenszeit..., s. 22-43.

73 Srov. HABERMAS, The structural..., s. 141-180.

74 Srov. OPASCHOWSKI, Pädagogik der freien Lebenszeit..., s. 22-43.

75 Srov. INAM, Forget...

76 Srov. INAM, Forget...

77 Srov. Hannah ARENDT, Vita activa neboli O činném životě, Praha: OIKOYMENH, 2009; Srov. PIEPER, Muße und Kult..., s. 43-50.

78 Srov. INAM, Forget..

79 Srov. LIPOVETSKY, Lére du vide..., s. 7-33; Srov. LIPOVETSKY, Les temps..., s. 11-47.

80 Srov. Jeanne NAKAMURA - Mihal CSIKSZENTMIHALYI, „The concept of flow.“ In: C. R. SNYDER - Shane J. LOPEZS (Eds.), Handbook of positive psychology, New York: Oxford University Press, 2002, s. 89-105.

81 Srov. OPASCHOWSKI, Pädagogik der Freizeit..., s. 28-56; Srov. OPASCHOWSKI, Paedagogik und Didaktik..., s. 32-64.

82 Srov. Karl MARX - Friedrich ENGELS, Das kommunistische Manifest. Berlin-Ost, 1955, s. 15.

83 Srov. OPASCHOWSKI, Pädagogik der freien Lebenszeit..., s. 22-43.

84 Srov. CONLEY, Elsewhere..., s. 145-177; Srov. SPITZER, Cyberkrank!..., s. 17-25.

85 Srov. CONLEY, Elsewhere..., s. 145-177. 
a zabývají se vším možným kolem, což je ve značné míře následek prohlubujícího se individualismu, který upřednostňuje sebekontrolu před tradičními zpơsoby normalizace, přičemž je ale doprovázen slabou vưlí a nevázaností. Výsledkem je pak jedinec neschopný odložit některé aktivity na později, nebot život je soustředěn na právě probíhající okamžik. ${ }^{86}$ Někteří dokonce podléhají přesvědčení, že jinak to nelze, naopak, že svůj čas využívají lépe. Moderní technologie totiž velkou část práce vykonají za ně, čímž jim zbývá čas, který nemusí promrhat, ale využít $\mathrm{k}$ nějaké další činnosti, bud' zábavě, či další práci. Už si ale neuvědomují, že žádnou z těchto činností nedělají pořádně, dokonce se domnívají, že jsou tak dobří, protože zvládají více činností najednou (multitasking) ${ }^{87}$ Ve výsledku není často jasné, zda právě pracují, nebo se baví, ale ani jedno nedosahuje podstaty, pro kterou je děláno. ${ }^{88}$ Podle Lipovetského ${ }^{89}$ jde o hyperaktivní kulturu zaměřenou na výkonnost, která nemá konkrétní smysl ani cíl, a je orientována pouze na to, co je ted' a tady. V hypermoderní době má člověk pocit časového nedostatku a nastává časový paradox: čím je člověk rychlejší, tím méně má času. Považovat tedy weisure za naplnění volnočasového životního stylu nelze, ba naopak, v mnohém jsou tyto dva životní styly v rozporu.

\section{Instrumentalizace volného času}

Weisure není fenoménem, se kterým se setkáváme jen u dospělých, již u dětí můžeme pozorovat známky weisure nebo instrumentalizovaného volného času (leisure nikoliv free time, jak bylo pojednáno v kapitole 2.2, nebot hranice mezi prací a volným časem mizí). Zatímco si děti dříve hrály, nyní se socializují s vrstevníky, dříve hnětly hlínu, ted' rozvíjí manuální zručnost prostřednictvím 3D pomůcek, dříve kopaly do míče, nyní tříbí své fyzické schopnosti, dříve hrály fotbal, ted' se učí fungovat $\mathrm{v}$ systému založeném na pravidlech a s institucionalizovanými dospělými autoritami (trenérem, vychovatelem). Může se zdát, že jde o totéž - jen s jiným pojmenováním. Často jde skutečně o stejné aktivity s novými názvy, ale často ani o stejné aktivity nejde. Mění se nejen to, co děti dělají, ale také, jak myslí, reagují. Mnohdy už ani nelze hovořit o volném čase, protože tento prostor mizí a místo něj je tu instrumentalizovaný leisure - weisure..$^{90}$

Není to v historii poprvé, kdy se setkáváme s instrumentalizací volného času. Již v roce 1892 se v Německu konala konference, kterou pořádala Berliner Centralstelle für Arbeiter-Wohlfahrtseinrichtungen, která se kromě jiných témat věnovala také otázce „jak účelně využít volný čas“. Volný čas byl novou oblastí života (jak bylo pojednáno v kapitole 2), která zejména v zemích silně ovlivněných protestantskou etikou vyvolávala otázky až obavy. ${ }^{91}$ Riziko spojené s časem, kdy si člověk může dělat co chce, což zahrnuje také to, že nemusí dělat nic, tedy nic užitečného a účelného, vedlo $\mathrm{k}$ pedagogizaci volného času. Tu můžeme pozorovat i později, v praxi totalitních režimů 20. století, nacismu a komunismu. S voláním po „smysluplném trávení volného času“ jakožto cíli pedagogiky volného času se však setkáváme i v současnosti, ${ }^{92}$ přičemž nejde o nic jiného než o instrumentalizaci volného času.

Dětem je dospělými organizován téměř veškerý čas, ${ }^{93}$ čímž volný čas částečně nebo i zcela ztrácí

86 Srov. BECK, Risikogesellschaft..., s. 113-246; Srov. LIPOVETSKY, L’empire..., s. 43-56.

87 Srov. SPITZER, Cyberkrank!..., s. 53-68.

88 Srov. CONLEY, Elsewhere..., s. 152-186; Srov. SPITZER, Cyberkrank!..., s. 53-71.

89 Srov. LIPOVETSKY, Les temps..., s. 11-47.

90 Srov. CONLEY, Elsewhere..., s. 144-152.

91 Srov. Max WEBER, Die protestanische Ethik und der Geist des Kapitalismus, München: Verlag C.H.Beck, 2004.

92 Srov. OPASCHOWSKI, Pädagogik der freien Lebenszeit..., s. 28-56; Srov. KAPLÁNEK, Pedagogika...; Srov. KAPLÁNEK, Volný čas..., s. 23-30.

93 Srov. () Peter GRAY, How we deprive children of the physical aktivity they need. Psychology Today. Posted Jun 29, 2018, dostupné na: https://www.psychologytoday.com/us/blog/freedom-learn/201806/how-we-deprive-children-the-physical-activity-they-need. 
povahu volného času a nabývá spíše charakter povinnosti. Pokud dětem ještě nějaký neorganizovaný čas zbyde, velmi často jej tráví hraním počítačových her, ${ }^{94}$ které je připravují pro jejich budoucí pracovní život. Učí je vydělávat peníze, nakupovat a prodávat, hromadit jmění, pěstovat a vyrábět různé suroviny, virtuálně krmit své dvojrozměrné zviŕrecí mazlíčky (nejznámější a nejrozšířenější je patrně Minecraft ${ }^{95}$, který nabízí i propojení se stavebnicí LEGO $^{96}$ ). Ovšem nejsou to jen počítačové hry, ale i celá řada her deskových, které jsou za tímto účelem vytvořené. ${ }^{97}$ Když pomineme možné negativní důsledky, které hraní počítačových her a užívání on-line technologií vůbec může mít na vývoj dítěte, ${ }^{98}$ jde o spojení práce a hry. U dětí i dospělých se tak práce podobá domovu a domov práci - rozdíl mezi privátní a veřejnou sférou je nejasný až nerozeznatelný. ${ }^{99}$ Nejenže jsou tak děti vystavovány kybernetickému způsobu socializace, ale současně jsou volitelně programovány na objednávku ${ }^{100}$ a formovány v životním stylu weisure.

Výchova ve volném čase spadá do oblasti neformálního vzdělávání, které je směrováno v návaznosti na vzdělávání formální, které se od roku 2012 v ČR uskutečňuje v souladu s Rámcovým vzdělávacím programem ${ }^{101}$, zavádějícím do školní výchovy pojem klíčových kompetencí (v Evropském kontextu se tento pojem v souvislosti se vzděláváním objevuje již v 90 . letech 20 . století). Jde o soubor znalostí, dovedností, postojů a hodnot, které si má jedinec osvojit jako základ, na němž bude stavět ve svém osobním a profesním životě. Díky osvojení klíčových kompetencí by mělo dojít $\mathrm{k}$ úspěšnému zařazení jedince do společnosti a zároveň k zajištění funkčnosti, ekonomické výkonnosti a konkurenceschopnosti společnosti jako celku. ${ }^{102}$ I když by při osvojování klíčových kompetencí nemělo jít pouze o aplikaci na úrovni tvorby materiálních hodnot, tedy o uplatnění na trhu práce a zařazení do pracovního procesu, jedná se o prioritní cíl. Pokud by totiž osvojení klíčových kompetencí mělo vést k uchopení vlastního bytí, porozumění sama sobě, vnímání svého života jako celku, jestliže by jedinec měl být schopen promýšlet svůj život ve vztahu $\mathrm{k}$ dalším lidem i společnosti ${ }^{103}$, pak by muselo jít především o výchovu hodnotovou (bude pojednáno v kapitole 5), ale tu koncept klíčových kompetencí zahrnuje jen velmi okrajově. ${ }^{104}$

Proměna volného času (at již ve smyslu free time či leisure) v pouhý nástroj - at již výchovného zhodnocování volného času, prevence rizik (skutečných, nebo často domnělých), nebo manipulace či trhu ${ }^{105}$ - a cílení výchovy na smysluplné (či efektivní) využití volného času (kapitola 2.1) je v mnohém položením základu pro rozvoj životního stylu weisure.

94 Srov. (C) Petr SAK, Proměny volného času a zaostávání pedagogiky, 2006, dostupné na: http://www.insoma.cz/index. php?id=1\&n=1\&d_1=paper\&d_2=2006_06a.

95 Srov. () Microsoft. Minecraft (online), 2019, dostupné na: https://minecraft.net/en-us.

96 Srov. () LEGO Group. LEGO (online), 2018, dostupné na: https://www.lego.com/cs-cz/themes/minecraft.

97 Srov. @ Dětský podnikatelský klub (online), 2019, dostupné na: http://www.detskypodnikatelskyklub.cz/nase-hry.

98 Srov. Manfred SPITZER, Demencia digital, Ediciones B, 2013, s. 119-201; Srov. SPITZER, Cyberkrank!...; Srov. @ Peter GRAY, Benefits of play revealed in research on video gaming. Psychology Today. Posted Mar 27, 2018, dostupné na: https://www.psychologytoday.com/us/ blog/freedom-learn/201803/benefits-play-revealed-in-research-video-gaming.

99 Srov. CONLEY, Elsewhere..., s. 144-152.

100 Srov. LIPOVETSKY, Lére du vide..., s. 12-32.

101 Srov. (C) Metodický portál RVP, Rámcový vzdělávací program pro základní vzdělávání (online). Praha: VÚP, 2007, dostupné na: http:// www.vuppraha.rvp.cz/wp-content/uploads/2009/12/RVPZV-pomucka-ucitelum.pdf, citováno dne 8. 3. 2019.

102 Srov. (C) Communication department of the European Commission, Lisabonská strategie (online), dostupné na: www.europa.eu, citováno dne 8. 3. 2019.

103 Srov. () UNESCO Digital Library, Learning: the treasure within. Report to UNESCO of the International Commission on education for the twenty-first century (online), dostupné na: https://unesdoc.unesco.org/ark:/48223/pf0000109590, citováno 8. 3. 2019.

104 Srov. Martina KOČEROVÁ - Petr BAUMAN, Rozvoj kritického a tvořivého myšlení v prostoru volného času, in: Kritické a tvořivé myšlení: není to málo?, ed. Petr BAUMAN, České Budějovice: TF JU, Centrum filozofie pro děti, 2013, s. 168-185.

105 Srov. KAPLÁNEK, Volný čas..., s. 24-93. 


\section{Weisure jako výzva pro pedagogiku volného času}

Pedagogika volného času zahrnuje nejen výchovu ve volném čase, ale také výchovu pro volný čas a výchovu volným časem. Mưžeme mluvit o třech rozměrech této výchovy: jedním je sama výchova, která zohledňuje specifické podmínky plynoucí z relativně svobodného rozhodování jedince v tomto časovém úseku jeho života; druhým je volný čas, jehož hodnotné využití se odvíjí od motivace a rozvinutých kompetencí; třetí pak jsou prostředky výchovy. ${ }^{106}$ Pokud zvažujeme úlohu pedagogiky volného času v souvislosti s fenoménem weisure, který se vyznačuje rozostřením až smazáním hranice mezi časem pracovním a volným, pak je třeba si položit otázku, zda všechny tři uvedené rozměry zůstávají aktuálními.

Pro zodpovězení této otázky je potřeba vymezit cílovou skupinu. Pedagogika volného času se v současném pojetí nezaměřuje pouze na děti a mládež (jak tomu bylo v případě užšího pojetí pedagogiky volného času navazujícího na mimoškolní výchovu), ale také na dospělé či seniory. Nicméně, vezmeme-li v potaz psychologický vývoj dle Eriksona ${ }^{107}$, pak s dospělostí nastupuje osobnostní zralost a ustává hluboké formování, které probíhá v období dětství a adolescence. Samozřejmě i v dospělosti je jedinec schopen do hloubky jdoucích změn, avšak tyto probíhají zejména v závislosti na jeho osobním rozhodnutí, význam výchovného působení jiných dospělých osob se snižuje a změny jsou obvykle časově náročnější než v období dětství.

Oproti tomu dětství a adolescence jsou vývojovými etapami osobnostního zrání, osobnost jedince není zatím zformována, jedná se o čas hledání, experimentování. Osobní rozhodnutí sice i v tomto věku hraje významný vliv při formování osobnosti, značnou roli hraje ovšem také působení druhých osob (především rodičů, pedagogů) a sociálního prostředí. ${ }^{108}$ Dá se při tom předpokládat, že osvojené vzorce chování, hodnotová orientace a dovednosti získané v dětství se stanou základem pro myšlení, zvažování, jednání jedince v dospělosti. Pokud je tedy v dětství položen základ pro instrumentalizaci volného času (jak bylo pojednáno v kapitole 4), s velkou pravděpodobností si jedinec tento přístup $\mathrm{k}$ volnému času přenese také do dospělosti. Naopak, pokud v dětství dojde k rozvoji takového myšlení, které směřuje $\mathrm{k}$ uvědomění si významu volného času pro kvalitu života, může být položen základ prevence rozvinutí životního stylu weisure jak u dítěte, tak v jeho dospělosti. Z uvedeného vyplývá, že primární cílovou skupinou, na kterou by se pedagogika volného času měla zaměřit v prevenci rozvoje životního stylu weisure, by měly být děti a mládež.

Životní styl weisure je provázen rozmlžením hranic, kdy není zřejmé, co je práce a co volný čas, co jsou pracovní aktivity a co zábava. A nebot tento trend nelze oddělit od vývojové etapy společnosti, v níž vznikl, souvisí weisure se snížením významu až ztrátou referenčních rámců sloužících za pevné body při orientaci jednotlivce v životě (pojednáno v kapitole 1). Individualizaci a personalizaci provází oslabování volních vlastností a nevázanost, což s sebou přináší absenci cílů a smyslu, ${ }^{109}$ oslabení schopnosti rozhodovat se, tudíž také neschopnost uchopit zodpovědně svou svobodu. Jednotlivec se zaměřuje primárně na přítomný okamžik, což je u dětí ještě více umocněno tím, že se z pohledu vývojových fází nachází v období konkrétního myšlení. S rozvojem abstraktního myšlení u mládeže ${ }^{110}$ sice nastává hlubší uvědomění si budoucnosti, nicméně ta je často vnímána jako neznámá, nejistá

106 Srov. Petr BAUMAN, Východiska pedagogiky volného času v perspektivě soudobých edukačních koncepcí, in: Volný čas a jeho význam ve výchově, ed. Michal KAPLÁNEK, Praha: Portál, 2017, s. 51-60.

107 Srov. Erik H. ERIKSON, The life cycle completed, New York: W. W. Norton \& Company, 1998.

108 Srov. Jan ČÁP - Jiř́ MAREŠ, Psychologie pro učitele, Praha: Portál, 2001; Srov. Jean PIAGET - Bärber INHELDER, The psychology of the child, New York: Basic Books, 2008; Srov. Lev S. VYGOTSKY, Concrete human psychology, Soviet Psychology 2/1989, s. 53-77.

109 Srov. LIPOVETSKY, Les temps..., s. 11-47.

110 Srov. ERIKSON, The life cycle..., s. 55-82. 
a tudíž nechtěná. Následkem je pak opět únik do současnosti, fixace na dětství a odmítání dospět. ${ }^{111}$ Weisure vzniká v návaznosti na užívání moderních technologií, čemuž jsou děti vystaveny již od útlého věku, což významně zasahuje do procesu socializace. Socializace dítěte do různých sociálních skupin je narušena a někdy i nahrazena kyber socializací (kapitola 3). ${ }^{112}$

Pedagogika volného času by se tedy u dětí a mládeže měla zaměřit na: (1) rozvoj volnočasových kompetencí; (2) hodnotovou výchovu; (3) rozvoj kritického myšlení a (4) socializaci. Rozvoj volnočasových kompetencí nesouvisí pouze s volným časem, ale s časem vůbec. Jde o soubor schopností, dovedností a vlastností, který jedince uschopňuje svobodně a přitom zodpovědně zacházet se svým časem, přičemž klíčovým faktorem je uchopení vlastní svobody. Rozvojem volnočasových kompetencí se buduje základ pro svobodné prožívání života a rozhodování se na základě vědomého a kritického zvažování s ohledem jak na osobní prospěch, tak zároveň i na prospěch společnosti. Volnočasové kompetence umožňují jedinci reflektovat své potřeby, kriticky porozumět sobě samému a zvažovat společenské souvislosti. ${ }^{113}$

Pro reflexi a kritické zvažování jsou klíčové hodnoty, které tvoří základ pro rozhodování se na základě kritérií. Formování hodnotového systému v dětství tvoří základ pro postoje a rozhodování v životě dospělého člověka. $S$ tím souvisí schopnost přijmout zodpovědnost za sebe sama, za svá rozhodnutí, za svůj život. ${ }^{114} \mathrm{~V}$ hodnotové výchově nejde především o zprostředkování hotového hodnotového vědění, nýbrž se jedná o hodnoty jako nástroj ovlivňování činnosti jedince, jeho motivace a životního rozvrhování. ${ }^{115}$ Hodnotová výchova a kritické myšlení nachází propojení v reflexi, která vede $\mathrm{k}$ překonání a transformaci nejasností, pochybností a konfliktních situací do stavu, který umožňuje najít rovnováhu v životě. ${ }^{116}$ Mělo by tedy jít nejen o hodnotovou výchovu, jejíž podstatou je přivedení ke smyslu pro hodnoty, ale také výchovu $\mathrm{k}$ hodnocení a $\mathrm{k}$ vědomé reflexi vlastních hodnocení. ${ }^{17}$

Volný čas je provázen navazováním neformálních vztahů, které dávají vzniknout neformálním sociálním skupinám, a jak bylo uvedeno v kapitole 2.2, někteří autoři leisure př́mo spojují s participací na společnosti a pocitem sounáležitosti. ${ }^{118}$ Jsou to skupiny, které vznikají na základě společných zájmů, kdy jedinec do určité skupiny není přidělen, ale chce do ní patřit. Volný čas je tedy pro budování vztahů př́hodnější než např. formální skupina, kterou je školní tř́ída, kam je dítě zařazeno, aniž by mohlo na tomto rozhodnutí jakkoliv participovat. Může tak snáze docházet k rozvoji sociálních kompetencí, které uschopňují jedince ke kontaktu se společností, při němž se budují vztahy a odbourávají sociální bariéry, a tím je vyrovnávána tendence $\mathrm{k}$ útěku ze společnosti a k privatizaci zájmů. Se sociální kompetencí úzce souvisí kompetence komunikativní, která zahrnuje schopnosti sdělovat a chápat, navazovat vztahy a společensky se chovat, čímž zabraňuje izolaci a napomáhá socializaci. ${ }^{119}$ Podstatou volného času je svoboda, a tudíž probíhající procesy mohou být rízeny či spoluřízeny samotnými účastníky na základě jejich vlastních rozhodnutí. Ve volném čase může převažovat sebekontrola nad kontrolou, je možné objevovat, odhalovat smysl a podstatu (kapitola 2) a učit

111 Srov. Benjamin R. BARBER, The global infantilization: how we become more and more "kidults" without noting loss of freedom in society, Der Tagesspiegel, September 9, 2001; Srov. Benjamin R. BARBER, Consumed: how markets corrupt children, infantilise adults and swallow citizens whole, New York: W. W. Norton, 2007; Srov. @ Martina KOČEROVÁ, Post-Adolescent Society as a Challenge for Education, Pedagogická orientace 4/2017, dostupné na: https://doi.org/10.5817/PedOr2017-4-520, s. 520-539.

112 Srov. SUE, Le loisir..., s. 31-52; Srov. SPITZER, Demencia..., s. 119-201.

113 Srov. OPASCHOWSKI, Pädagogik der freien Lebenszeit...; Srov. PIEPER, Muße und Kult...

114 Srov. ERIKSON, The life..

115 Srov. Naděžda PELCOVÁ, Hodnotová výchova a výchova k hodnocení, Pedagogika 10/2013, s. 285-300.

116 Srov. John DEWEY, How we think. A restatement of the relation of reflective thinking to the educative process, Boston: D.C., 1933.

117 Srov. PELCOVÁ, Hodnotová...

118 Srov. HAVIGHURST, Employment...; Srov. KAPLAN, Leisure...; Srov. Robert A. STEBBINS, Leisure and Positive Psychology: Linking Activities with Positiveness, London: Palgrave Macmillan, 2015.

119 Srov. KAPLÁNEK, Volný čas... 
se z chyb, nebot procesy probíhající ve volném čase nemusí být primárně zaměřeny na výsledky, př́p. těchto výsledků nemusí být dosaženo v předem určeném čase. Dítě se může zcela ponořit do procesu, zkoumat různé varianty řešení, experimentovat, nedělat nic a dokonce se úmyslně vydat cestou, o které ví, že k cíli nevede, a to jen proto, aby získalo tuto zkušenost, či ověřilo zprostředkovanou teoretickou znalost (rozvoj kulturní a kreativní kompetence). Může se učit stanovovat si cíle, rozhodovat se a vzít zodpovědnost za svá rozhodnutí v míře, která odpovídá jeho aktuálnímu stupni vývoje, a připravovat se tak na převzetí zodpovědnosti za svůj život v dospělosti. ${ }^{120}$ Jak bylo ale uvedeno na začátku této kapitoly, v dětském věku se na formování životního stylu dítěte podílí zejména dvě významné skupiny, jimiž jsou rodiče a pedagogičtí pracovníci (v pojetí tohoto článku zejména pedagogové volného času). Jsou to právě oni, kdo v největší míře ovlivňují podobu volného času dítěte, proto by pedagogika volného času měla cílit také na ně. Pedagogika volného času by v souladu se svými úkoly měla být rodičům nápomocna při jejich rozhodování o způsobu trávení volného času jejich dětí, aby v co nejnižší míre docházelo k instrumentalizaci volného času (jak bylo uvedeno v kapitole 4). Pedagogika volného času by se v této oblasti měla soustředit zejména na publikování literatury, ale zároveň také na pořádání seminářů a přednášek určených pro rodiče pojednávajících nejen o možnostech trávení volného času, ale zejména o hodnotové výchově vedoucí ke kritickému pochopení sebe sama a k reflexi společenských souvislostí. ${ }^{121}$

Co se týká pedagogů volného času, mělo by jít především o jejich profesní přípravu, která se ovšem nedá oddělit od osobnostního růstu. V České republice není žel této přípravě věnována patřičná pozornost a společenská prestiž profese pedagoga volného času není př́liš vysoká (je spíše nízká, což dokládají i legislativní dokumenty týkající se nároků na profesní přípravu pedagogů volného času ${ }^{122}$ ). Důsledkem toho se pak v praxi často setkáváme s pedagogy, kteří se zaměřují primárně na plánování a realizaci programové nabídky a mnohem méně na promýšlení možností rozvoje schopností a osvojování takových dovedností, které dítěti umožní uvědomit si, kým je, a to nejen v kontextu společnosti a kultury, do které patří, ale i v celoživotním kontextu. ${ }^{123}$ Jde pak často o pedagogy, kteří více akcentují správnost postupu a líbivost aktivit než vytváření prostoru pro kladení otázek, zvažování dilemat, konfrontování sama sebe v různých situacích, hledání řešení, rozhodování a přijetí zodpovědnosti.

Pokud totiž má jít především o hodnotovou výchovu (jak bylo pojednáno výše v souvislosti s dětmi a mládeží), nemůže jít o pouhou realizaci aktivit a činností, a to i přes jejich atraktivitu, zábavnost či smysluplnost. Pokud totiž zaměníme výchovné působení ve volném čase za naplnění volného času aktivitami a činnostmi, může být výsledkem právě instrumentalizace volného času a rozvoj životního stylu weisure. Namísto učení se zacházet se svobodou, zodpovědností, vytrvalostí, místo hledání smyslu se dítě učí konzumovat volnočasové aktivity, bavit se a selektivně si vybírat dle momentální nálady či módy.

Hodnotová výchova a s ní související rozvoj volnočasových kompetencí, kritického myšlení a reflexivní praxe ${ }^{124}$ však klade poměrně vysoké nároky na pedagogy, u nichž je nezbytné, aby svou sebevýchovu vedli ve stejném duchu. Aby se zabývali více reflexí současné situace s akcentem na

120 Srov. Peter GRAY, Play as a foundation for hunter-gatherer social existence, American Journal of Play, Spring 1/2009, s. 476-522; Srov. David F. LANCY, Teaching: natural or cultural?, in: Evolutionary perspectives on child development and education, ed. David C. GEARY - Daniel B. BERCH, New York: Springer, 2016, s. 33-65.

121 Srov. OPASCHOWSKI, Pädagogik der freien Lebenszeit...

122 Srov. (C) Zákon č. 563/2004 Sb., o pedagogických pracovnících a o změně některých zákonů, dostupné na: http://www.msmt.cz/file/38850/, citováno dne 8. 3. 2019; Srov. Vyhláška č. 317/2005, o dalším vzdělávání pedagogických pracovníkủ, akreditační komisi a kariérním systému pedagogických pracovníků, dostupné na: http://www.msmt.cz/file/38840/, citováno dne 8. 3. 2019.

123 Srov. () UNESCO Digital Library, Learning...

124 Srov. DEWEY, How we think... 
rozvíjející se postmoderní životní styl než vytvářením široké nabídky volnočasových aktivit, která ovšem nemusí nutně znamenat výchovu hodnotovou, často ani hodnotnou. Primárním by tedy ve volnočasové výchově nemělo být vytváření bohaté nabídky aktivit, př́ípadně vršení zážitků, ale učení se promýšlet, zvažovat, reflektovat. Aktivity by měly být pouze prostředkem či prostředím k přemýšlení o sobě, smyslu svého života, které bude následováno formováním hodnotové orientace a kritického myšlení.

\section{Závěr}

Weisure je spojen s rozostřením až smazáním hranic mezi prací a volným časem (pojednáno v kapitole 1) a s životem lidí v současné tzv. západní společnosti. Zda se jedná o společnost v pozdní fázi modernity ${ }^{125}$, nebo o postmoderní1 ${ }^{126}$, či dokonce hypermoderní ${ }^{127}$ společnost, je předmětem diskuzí, které přesahují rámec tohoto článku. Avšak at již budeme současnost nazývat jakýmkoliv z uvedených názvů, zřejmé je, že život společnosti i jedince zaznamenává změny. Zatímco v době, kterou Lipovetsky ${ }^{128}$ nazývá moderní, byl jedinec jasně veden $\mathrm{k}$ disciplíně směřující k normalizovanému a standardizovanému chování, současnost se vyznačuje individualizací a personalizací. Jednání člověka již není vedeno tradicí, ale odvíjí se od co největší možnosti soukromé volby. Tradiční způsoby normalizace zeslabují svůj vliv, do popředí se dostává důraz na svobodu a sebekontrolu, na druhé straně je personalizace provázena slabou vůlí, tudíž také nízkou vnitřní motivovaností (kapitola 1 ).

Jakou úlohu může ve společnosti, kde se mísí volný čas a práce, zastávat pedagogika volného času? Nepozbývá smyslu? At se již zaměříme na pojetí pedagogiky volného času vycházející z mimoškolní výchovy, jak byla rozvíjena zejména v tzv. socialistickém bloku, nebo na pedagogiku volného času v pojení německém, tedy jako na otevřenou práci s dětmi a mládeží, v obou pojetích byl volný čas jasně vymezen. Jasně formulován byl také cíl pedagogiky volného času, jímž bylo naučit děti a mládež smysluplně trávit volný čas (kapitola 2.1). At již byla ona smysluplnost dána skutečným zájmem o rozvoj osobnosti dítěte, výchovou ideologickou nebo prevencí sociálně patologických jevů, vedla postupně k pedagogizaci a instrumentalizaci volného času (kapitola 4). S vývojem společnosti se ale důraz na smysluplné trávení volného času ukazuje jako neaktuální (kapitola 5). Současná společnost přináší nové výzvy i pro pedagogiku volného času. Vyvstává dokonce otázka, jestli má pedagogika volného času ještě vůbec své místo v době životního stylu weisure, kdy jasné hranice volného času mizí. Životní styl weisure se týká především vyspělých západních zemí, ale jestliže se zaměříme na volnočasovou výchovu $\mathrm{v}$ těchto zemích, zjistíme, že tato není nijak významně rozvíjena a uplatňována. Zatímco např̀ v minulosti v USA bylo téma výchovy pro volný čas významnou součástí diskurzu o koncepci vzdělávání, v současnosti není tento aspekt v dokumentech americké vzdělávací politiky významně tematizován. ${ }^{129}$ Obdobně je tomu v Německu, kde se ve 20. století rozvíjel obor Pedagogika volného času, avšak po diskusích o (ne)vhodnosti pedagogizace času svobody se od výchovného zaměření ustupuje (v současnosti jde zejména o pedagogický výzkum volného času). ${ }^{130}$ Ztratila snad tedy pedagogika volného času skutečně svůj význam?

Situace v České republice je poněkud odlišná. Pedagogika volného času pojímá nejen výchovu ve volném

125 Srov. Zygmunt BAUMAN, The liquid modernity, Cambridge: Polity Press, 2000.

126 Srov. Jean-Françis LYOTARD, Toward the postmodern, New York: Humanity Books, 1998; Srov. Jean BAUDRILLARD, The consumer society: myths and structures, London: Sage Publications, 1998.

127 Srov. LIPOVETSKY, Les temps...

128 Srov. LIPOVETSKY, Lére du vide...; Srov. LIPOVETSKY, Les temps...

129 Srov. BAUMAN, Východiska...

130 Srov. KAPLÁNEK, Pedagogika... 
čase, ale také výchovu pro volný čas a výchovu volným časem. Můžeme mluvit o třech rozměrech této výchovy: jedním je sama výchova, která zohledňuje specifické podmínky plynoucí z relativně svobodného rozhodování jedince v tomto časovém úseku jeho života; druhým je volný čas, jehož hodnotné využití se odvíjí od motivace a rozvinutých kompetencí; tř̌etí jsou pak prostředky výchovy. ${ }^{131}$ Odpovídá ale takto pojatá pedagogika volného času aktuální situaci, kdy se ztrácí jasné hranice volného času? Podíváme-li se na život dětí a mládeže (jakožto primární cílové skupiny, jak bylo pojednáno v kapitole 5), můžeme vidět, že volný čas jako časová kategorie nevymizel. Co se smazává, je podstata volného času, která je do velké míry ovlivněna instrumentalizací a pedagogizací volného času (kapitola 4). Volný čas nabývá charakteru povinnosti, čímž je snižován potenciál, kterým disponuje. A právě tento vývoj zakládá na významu pedagogiky volného času, která by měla své úsilí zaměřit nejen na děti a mládež, ale také na edukaci rodičů a pedagogů volného času, kteří se na instrumentalizaci a pedagogizaci volného času v mnohém podílí (kapitola 5).

Volný čas je časem svobody a tohoto atributu by neměl být zbavován. Není to ale svoboda vytržená z kontextu společnosti, nýbrž svoboda umožňující formování hodnotového základu, a to v návaznosti na osobní zkušenosti a v kontextu skupiny. Je to svoboda vystavující člověka nutnosti zvažovat, rozhodovat se a poskytující prostor k zakoušení důsledků svých rozhodnutí, at již se týkají výhradně osoby daného jedince, nebo i celé skupiny. Tím se jedinec učí uvažovat v širším kontextu (jak společenském, tak časovém) a přijímat zodpovědnost za svá rozhodnutí. Dokonce může zakusit tzv. paradox svobody, kdy na základě vlastního svobodného rozhodnutí svou svobodu omezí, a to bud' proto, že jemu osobně to přinese prospěch, nebo proto, že upřednostní zájem druhých. Dítě se tak učí se svobodou pracovat jak v kontextu svého života, tak i společnosti. A tak vidíme, že volný čas v sobě skrývá velký potenciál pro formaci, na druhou stranu je právě jí ohrožen a to zejména, když úmyslná formace vytlačí neúmyslnou a spontánní.

Pedagogika volného času má tedy své místo i v současné společnosti. Co se mění v návaznosti na vývoj společnosti, jsou její cíle, metody či formy práce. Již nejde o smysluplné trávení volného času, ale o hodnotovou výchovu, rozvoj volnočasových kompetencí, rozvoj kritického myšlení a socializaci. Životní styl weisure neubírá na významu pedagogiky volného času, jak by se snad mohlo očekávat, ale naopak, zejména úloha výchovy pro volný čas je zdưrazněna. Nebot’ bez volného času je ohrožena kvalita života jak jednotlivce, tak společnosti. Akcentována je také výchova ve volném čase, nebot' jde o prostor, v němž je možné zaměřit se více na hledání podstaty života člověka než v čase povinností. A nezůstává stranou ani výchova skrze volný čas, nebot’ základním atributem volného času je svoboda, a jak příhodněji vést současného člověka k umění svou svobodu zodpovědně uchopit v kontextu života svého i společnosti než svobodou samou.

\section{Kontakt:}

\section{Mgr. Martina Kočerová}

Katedra pedagogiky, Teologická fakulta, Jihočeská univerzita v Českých Budějovicích

Kněžská 8, 37001 České Budějovice

martina.kocerova@tf.jcu.cz 